\title{
Tentative Characterization of New Environmental Giant Viruses by MALDI-TOF Mass Spectrometry
}

\author{
Bernard La Scola Angélique Campocasso Rolande N'Dong Ghislain Fournous \\ Lina Barrassi Christophe Flaudrops Didier Raoult
}

Pôle des Maladies Infectieuses, Assistance Publique-Hôpitaux de Marseille and URMITE UMR CNRS-IRD 6236, IFR48, Faculté de Médecine, Université de la Méditerranée, Marseille, France

\section{Key Words}

Giant virus, characterization $\cdot$ Marseillevirus $\cdot$ Mimivirus .

MALDI-TOF $\cdot$ Nucleocytoplasmic large DNA viruses

\begin{abstract}
Objective: Metagenomic studies have revealed that Acanthamoeba polyphaga Mimivirus relatives are common in the environment; however, only three Acanthamoeba-growing giant viruses have been isolated from hundreds of environmental samples. We attempted herein to isolate new Acanthamoeba-growing giant viruses from environmental samples. Methods: We inoculated 105 environmental samples by our usual procedure but with the addition of selected antibiotics to inhibit bacterial overgrowth. Results: We isolated 19 giant viruses with capsid sizes of 150 to $600 \mathrm{~nm}$, including one associated with a virophage. For the first time some were isolated from saltwater and soil samples. Tentative characterization using the PolB gene sequence was possible for some of these viruses. They were closely related to each other but different from the two previous isolates of Acanthamoeba polyphaga Mimivirus. Results obtained by MALDITOF MS analysis of viral particles were congruent with that of PolB sequencing. Conclusion: Our data confirm that Acan-
\end{abstract}

thamoeba-growing giant viruses are common in the environment. Additionally, MALDI-TOF MS analysis can be used for the initial screening of new viruses to avoid redundant analysis. However, due to their genetic variability, it is likely that the genome sequences of most of these viruses will have to be determined for accurate classification.

Copyright $\odot 2010$ S. Karger AG, Basel

\section{Introduction}

Free-living amoebae, such as Acanthamoeba spp., are ubiquitous microorganisms that live in many environments, mostly water and soil [1]. These amoebae use environmental bacteria as food; however, some bacteria have developed strategies to resist phagocytosis by amoebae or to survive intracellularly when phagocytized. Several bacteria avoid phagocytosis by producing toxins, pigments or particular structures on their external membrane $[2,3]$. Others have developed strategies that allow them to avoid the bactericidal effect of amoebae, using amoeba as a protected niche for growth, and may have even become strict intracellular microorganisms unable to grow or survive outside amoebae cells $[4,5]$. The inter-

\section{KARGER}

Fax +4161306 1234

E-Mail karger@karger.ch

www.karger.com
(C) 2010 S. Karger AG, Basel

0300-5526/10/0535-0344\$26.00/0

Accessible online at:

www.karger.com/int
Prof. Bernard La Scola

URMITE, Faculté de Médecine

27 Boulevard Jean Moulin

FR-13385 Marseille Cedex 5 (France)

Tel. +33 49132 4375, Fax +33 49138 7772, E-Mail bernard.lascola@ univmed.fr 
est of clinical microbiologists in amoeba-associated bacteria was triggered when TJ Rowbotham demonstrated that the human pathogen Legionella pneumophila was naturally able to grow within several species of amoebae, suggesting that they were the natural reservoir of this pathogen in the environment $[6,7]$. After this preliminary work, Rowbotham extensively used amoebae in a shell vial system as a support for the isolation of Legionella spp. from humans and the environment $[8,9]$. Our collaboration with Rowbotham began when RJ Birtles moved from Rowbotham's laboratory to ours for a postdoctoral position to identify a part of Rowbotham's collection by using $16 \mathrm{~S}$ rRNA gene amplification and sequencing [10-13]. Among isolates of this collection, one small Gram-positive microorganism resisted identification until we determined that it was not a bacterium but a giant virus, later named Acanthamoeba polyphaga Mimivirus (APM) [14]. At the time, we hypothesized that giant viruses are very scarce in the natural environment because after inoculating more than 1,200 environmental samples from diverse origins for new amoebal pathogens [15-19], we only isolated two additional giant viruses. One, named Mamavirus, was an APM infected by a virophage [20], and the other was representative of a new virus family half the size of APM, named Marseillevirus [Boyer, in press]. These results were discrepant with those of metagenomic studies performed on environmental sample that showed that APM should be common in nature $[21,22]$. Therefore, in the last two years, we slightly modified our isolation procedures, and this has allowed us to isolate 19 additional giant viruses and a new virophage in 105 environmental samples. In the present work, we detail the conditions of isolation of our 19 new giant virus isolates. To avoid complete genome sequencing of all new isolates that will be obtained in the future, we tentatively used matrix-assisted laser desorption ionization time-of-flight mass spectrometry (MALDI-TOF MS) on purified viruses and partial PolB gene amplification and sequencing to provisionally characterize these new giant viruses.

\section{Materials and Methods}

\section{Environmental Samples}

A total of 105 samples were tested. Most samples came from water sources: 39 cooling tower water samples, 28 river and lake samples, 13 decorative fountain samples, 10 tap water samples, 12 hospital water samples and 10 seawater samples. We also tested two soil samples and the liquid from a contact lens of a patient with keratitis, in which the presence of Acanthamoeba spp. DNA was detected by PCR amplification. For water, 500-ml samples were filtered through a $0.22-\mu \mathrm{m}$ pore filter, and these filters were then shaken in $2 \mathrm{ml}$ of sterile Page's amoebal saline (PAS). From each sample, $100 \mu \mathrm{l}$ of this suspension was inoculated onto amoebal microplate suspensions. For soil samples, $100 \mathrm{~g}$ of sample were diluted in $500 \mathrm{ml}$ of sterile distilled water and then submitted to the following three-step filtration: first, samples were passed through a $40-\mu \mathrm{m}$ Falcon cell strainer, then through paper filters, and finally filtered through a $0.22-\mu \mathrm{m}$ membrane. The membrane was then treated as above. For the contact lens liquid, $50 \mu \mathrm{l}$ of liquid was inoculated in $10 \mathrm{ml}$ of PAS enriched with live Enterobacter aerogenes. Some amoeba cysts were observed just after inoculation but, immediately after excystation, they disappeared. We suspected that this could be due to a virus. We thus filtered the $10 \mathrm{ml}$ of culture through a $0.22-\mu \mathrm{m}$ pore filter and treated it for viral isolation as described below.

\section{Preparation of Amoebal Microplates and Isolation by}

Co-Culture with Amoebae

Amoebal microplates were prepared with Acanthamoeba polyphaga (strain Linc AP-1), under previously described conditions [23]. Each sample was inoculated onto two series of amoebal microplates, i.e. without antibiotics and with $10 \mu \mathrm{l}$ colimycin at $500 \mathrm{UI} / \mathrm{ml}$ (Colistine, Aventis Pharma) and $10 \mu \mathrm{l}$ vancomycin at $10 \mu \mathrm{g} / \mathrm{ml}$ (vancomycin chlorhydrate, Merck). Co-cultures were systematically sub-cultured onto a fresh amoebal microplate suspension. Primary and subcultures were screened daily for cytopathogenic effects with an inverted microscope under $400 \times$ magnification, and 100- $\mu$ l samples of resuspended amoebae (taken every 3 days) were cytocentrifuged and stained with methylene blue, Gimenez [24], Gram, hemacolor (Merck, Darmstadt, Germany) and DAPI [25]. On each microplate, one well was maintained as a negative control, with only an amoebal monolayer to check bacterial contamination, if any. At day seven, $50 \mu \mathrm{l}$ of each co-culture was systematically sub-cultured onto axenic media, BCYE and Columbia sheep blood agar plates to evaluate residual bacterial contamination. The antimicrobial susceptibility of the obtained isolates was tested using the disk diffusion assay. The antibiotics tested included gentamicin, cotrimoxazole, erythromycin, rifampicin, doxycycline and ciprofloxacin. If bacterial overgrowth was moderate, the antibiotics that tested as effective on isolated bacteria were added to subcultures at final concentrations above the MIC of the contaminating bacteria. If bacterial overgrowth was massive and destroyed the amoeba monolayer, the sample was re-inoculated and supplemented with one or more of the effective antibiotics. In cases where the bacterial overgrowth was due to bacteria not growing on agar plates, we serially tested different antibiotics on subcultures or re-inoculations.

\section{Preparation of Viral Co-Cultures for Cloning}

To perform further work on pure viruses, all of the isolated viruses were cloned. Before cloning, lack of bacterial contamination was checked by inoculation of a subculture onto agar plates and Gram/Gimenez staining. Culture supernatant containing viral particles was filtered through $0.8-\mu \mathrm{m}$-pore filters and then serially diluted from $10^{-1}$ to $10^{-11}$. Two 24 -well microplates, containing $1 \mathrm{ml}$ of a suspension containing rinsed amoebae at $105 / \mathrm{ml}$ in PAS, were then prepared, and four wells were inoculated with each dilution. Amoebal lysis in microplates incubated 
at $32^{\circ}$ was monitored daily with an inverted microscope. When amoebal lysis was almost complete, the well containing the highest dilution that lead to lysis was used for virus production by successive subculturing. The sample was tested again for lack of bacterial contamination by subculturing on an agar plate, as described above, and $16 \mathrm{~S}$ rRNA gene amplification, under previously described conditions [26]. The size of viral particles was determined using electronic microscopy observation after negative staining.

\section{Genome Sequences}

Production of the earliest obtained viruses allowed us to perform genome sequencing. Large amounts of co-cultures were prepared and then filtered through 0.8 - and $0.2-\mu \mathrm{m}$ membranes. Viruses were obtained by washing the $0.2-\mu \mathrm{m}$ membranes with $\mathrm{K} 36$ buffer. DNA was extracted following the Mimivirus procedure [27]. The genomes of the viruses were then sequenced separately on a 454-Roche GS20, according to Margulies [28]. Genomes of four viruses were sequenced (Moumou, Terra1, Terra2 and Courdo11) and are currently under analysis. Reads obtained from the GS20 were assembled de novo with Newbler Assembly software (Roche).

\section{B-Family DNA Polymerase Amplification and Sequencing}

Nucleotide alignments of Mimivirus, Mamavirus, Moumou, Courdo11, Terral and Terra2 were performed to design primer pairs for the conserved region of PolB. According to this analysis, we designed a primer pair to amplify the Mimivirus, Mamavirus and Terra2 PolB genes, a primer pair to amplify the Courdo11 and Terral genes and a primer pair to amplify Moumou PolB. A last primer pair was also designed for the PolB of Marseillevirus. All of these primers were tested on all viruses in the collection. Sequences of primers and amplifiates are shown in Table S1 of the supplementary material for this paper (available online at www. karger.com/doi/10.1159/000312919).

\section{MALDI-TOF MS}

For each test, four $75-\mathrm{cm}^{2}$ cell culture flasks of virus-infected amoeba were collected in centrifugation tubes after lysis and then filtered through $0.8-\mu \mathrm{m}$ membranes. The filtrate was centrifuged $(9,000 \mathrm{rpm}$ for $15 \mathrm{~min})$, and the pellet was rinsed three times with sterile distilled water, and ultracentrifuged $(24,000 \mathrm{rpm}$ for $1 \mathrm{~h})$ on $25 \%$ sucrose. After centrifugation, the pellet was dissolved in $10 \mu \mathrm{l}$ of distilled water, and $1 \mu \mathrm{l}$ of the suspension was deposited on a MALDI-TOF MTP 384 target plate (Bruker Daltonik, Leipzig, Germany). Four deposits were made for each virus, with an estimated number of $10^{6}$ viral particles per deposit. The preparation was overlaid with $2 \mu \mathrm{l}$ of matrix solution [a saturated solution of $\alpha$-HCCA (alpha-cyano-4-hydroxycinnamic acid) in 50\% acetonitrile, $2.5 \%$ tri-fluoracetic-acid]. The matrix sample was crystallized by air drying at room temperature for $5 \mathrm{~min}$. Measurements were performed with an Autoflex II mass spectrometer (Bruker Daltonik) equipped with a $337-\mathrm{nm}$ nitrogen laser. Spectra were recorded in the positive linear mode (delay $170 \mathrm{~ns}$, ion source 1 voltage $20 \mathrm{kV}$, ion source 2 voltage $18.5 \mathrm{kV}$, lens voltage $7 \mathrm{kV}$, mass range $2-20 \mathrm{kDa}$ ). Each spectrum was obtained after 675 shots in automatic mode with variable laser power, and the acquisition time ranged from 30-60 s per spot. Data were automatically acquired using AutoXecute acquisition control software. The four raw spectra obtained for each isolate were imported into BioTyp-
Table 1. Particle and actual genome size of giant viruses studied, according to the origin of the sample

\begin{tabular}{|c|c|c|c|c|}
\hline $\begin{array}{l}\text { Sample } \\
\text { isolates/tested }\end{array}$ & Name & Strain & $\begin{array}{l}\text { Capsid } \\
\text { size } \\
\mathrm{nm}\end{array}$ & $\begin{array}{l}\text { Genome } \\
\text { size } \\
\mathrm{Mb}\end{array}$ \\
\hline \multirow{5}{*}{$\begin{array}{l}\text { Cooling towers } \\
5 / 39(13 \%)\end{array}$} & Moumou & M10A & 420 & 1.2 \\
\hline & Monve & MV13 & 390 & NA \\
\hline & Bus & RTM2 & 400 & NA \\
\hline & Cannes8 & $8 \mathrm{~A}$ & 190 & NA \\
\hline & Cannes9 & $9 B$ & 150 & NA \\
\hline \multirow{3}{*}{$\begin{array}{l}\text { Decorative } \\
\text { fountains } \\
3 / 13(23 \%)\end{array}$} & Longchamps & FPL & 450 & NA \\
\hline & Montpellier & MTP3 & 370 & NA \\
\hline & Saintcharles & FSC & 230 & NA \\
\hline \multirow{5}{*}{$\begin{array}{l}\text { Rivers and } \\
\text { lakes } \\
5 / 28(18 \%)\end{array}$} & Courdo11 & CE11 & 450 & 1.25 \\
\hline & Courdo5 & CE5 & 400 & NA \\
\hline & Courdo7 & CE7 & 400 & NA \\
\hline & Cher & Cher & 420 & NA \\
\hline & Lactours & LT2 & 450 & NA \\
\hline \multirow{2}{*}{$\begin{array}{l}\text { Soil } \\
2 / 2(100 \%)\end{array}$} & Terral & TAOTE1 & 420 & 1.3 \\
\hline & Terra2 & TAOTJA2 & 370 & 1.3 \\
\hline \multirow{2}{*}{$\begin{array}{l}\text { Seawater } \\
2 / 10(20 \%)\end{array}$} & Pointerouge1 & PR1 & 390 & NA \\
\hline & Pointerouge2 & PR2 & 500 & NA \\
\hline $\begin{array}{l}\text { Hospital water } \\
1 / 12(8 \%)\end{array}$ & Fauteuil & FD & 600 & NA \\
\hline $\begin{array}{l}\text { Lens liquid } \\
1 / 1(100 \%) \\
\end{array}$ & Lentille* & $C L^{*}$ & 500 & NA \\
\hline \multirow{3}{*}{$\begin{array}{l}\text { Previous studies } \\
\text { on cooling } \\
\text { towers }\end{array}$} & Mimivirus & $\mathrm{BC}$ & 400 & 1.2 \\
\hline & Mamavirus & Halles & 450 & 1.2 \\
\hline & Marseillevirus & T19 & 230 & 0.368 \\
\hline
\end{tabular}

* Strain associated with a virophage.

$\mathrm{er}^{\mathrm{TM}}$ version 2.0 software (Bruker Daltonik) and analyzed with $\mathrm{R}$ project software (http://www.r-project.org). Non-reproducible picks were removed, and picks intensity was normalized. A matrix was then built on the presence or absence of picks above the threshold intensity. The matrix was then used to build a dendrogram.

\section{Results}

\section{Giant Virus Isolates, Genome and Particle Size Evaluation}

In this present study, we isolated 19 viruses from 105 samples, and giant viruses were isolated in each type of sample tested (table 1). As an example of what is observed during the isolation process, morphologic data obtained with virus $9 \mathrm{~b}$ are presented in figure 1 . Among the sam- 

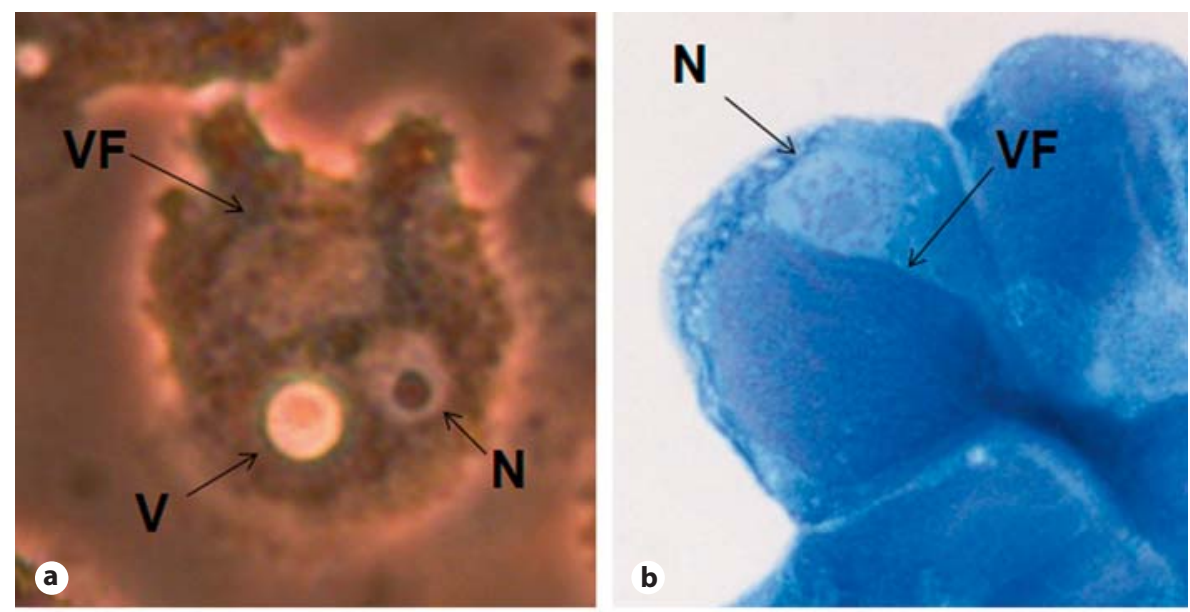

Fig. 1. Morphologic analysis of virus Cannes9 growing in A. polyphaga, as seen before lysis of the amoeba. a Inverted microscopic observation of viral infection. b Methylene blue staining: the virus factory appears as a pink-stained structure; the nucleus appears as a light structure. c On Gimenez staining, some viral particles appear in pink. d Negative staining electron microscopy of Cannes9 virus with its icosahedral particle surrounded by fibrils. $\mathrm{VF}=$ Virus factory; $\mathrm{N}=$ nucleus; $\mathrm{V}=$ vacuola.
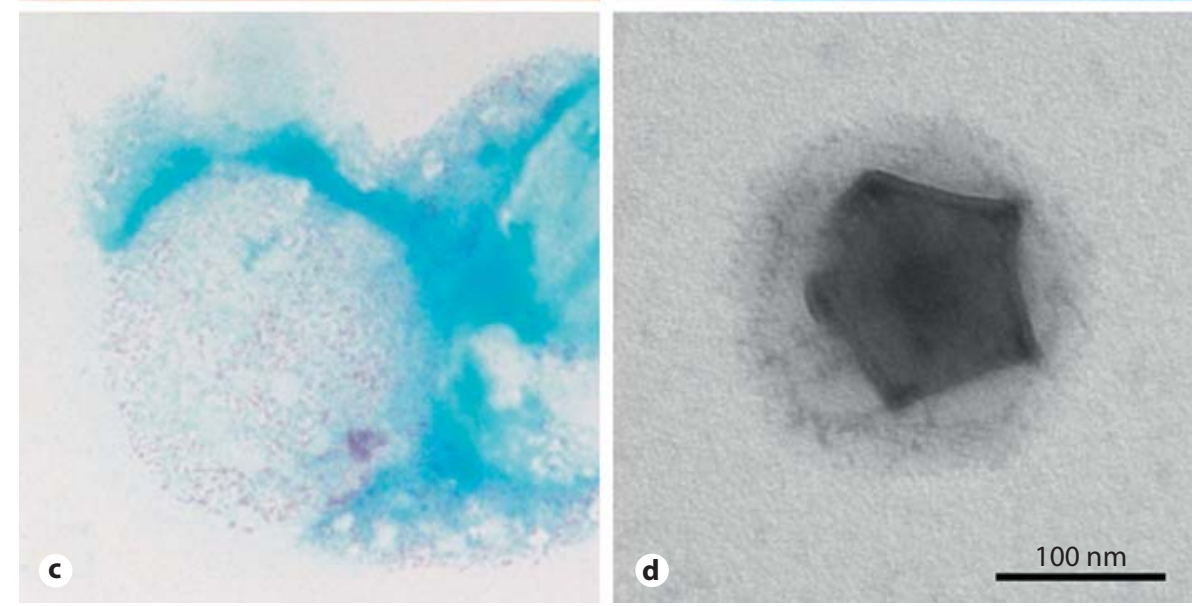

ples tested, soils and contact lens liquid were the most frequently positive, as the three samples tested were all positive. For other samples, the frequency of isolation of giant viruses for water samples from decorative fountains, seawater, river and lakes, cooling towers and hospital water was $23,20,18,13$ and $8 \%$, respectively. The virus sizes varied from 150 to $600 \mathrm{~nm}$. It should be noted that evaluation of particle size using negative staining is more approximate than that obtained by transmission electronic microscopy. However, viruses could be clustered in three groups based on size: large viruses of at least $500 \mathrm{~nm}$ (e.g. Lentille, Pointerouge2, Fauteuil); small viruses below $250 \mathrm{~nm}$ (e.g. Cannes8, Cannes9, Saintcharles), and those with an intermediate size of approximately $400 \mathrm{~nm}$, which make up the majority of viruses (fig. 2). A unique putative virophage of $50 \mathrm{~nm}$ in size was also observed associated with Lentille giant virus (fig. 3). Morphologically, it was comparable to the virophage isolated with Mamavirus [20].

Tentative Characterization of New Giant Viruses

\section{Raw Genome Sequence and PolB Amplification and Sequencing}

The current state of assembly of the virus genomes is sufficient to study their contents in Terral (1.13 Mb in 26 contigs), Terra2 (1.13 Mb in five contigs), Courdo11 (1.25 $\mathrm{Mb}$ in 20 contigs) and Moumou (1.2 Mb in five contigs). A tree built with the available complete PolB genes shows that Terra 2 is closely related to Mimi/Mamavirus, Terra1 is closely related to Courdo11, and Moumou is more distantly related to these viruses. They represent a monophyletic cluster, well separated from other nucleocytoplasmic large DNA viruses (NCLDV) including Marseillevirus, but cluster in the group of Phycodnaviridae (fig. 4). Due to the small size of the amplified fragments and quality of sequences obtained, it was not possible to build a tree for all viruses. We thus built four trees corresponding to the four amplified areas (online suppl. fig. 1-5). Unfortunately, the small sizes of the fragments analyzed do not permit clear phylogenetic classification

Intervirology 2010;53:344-353 

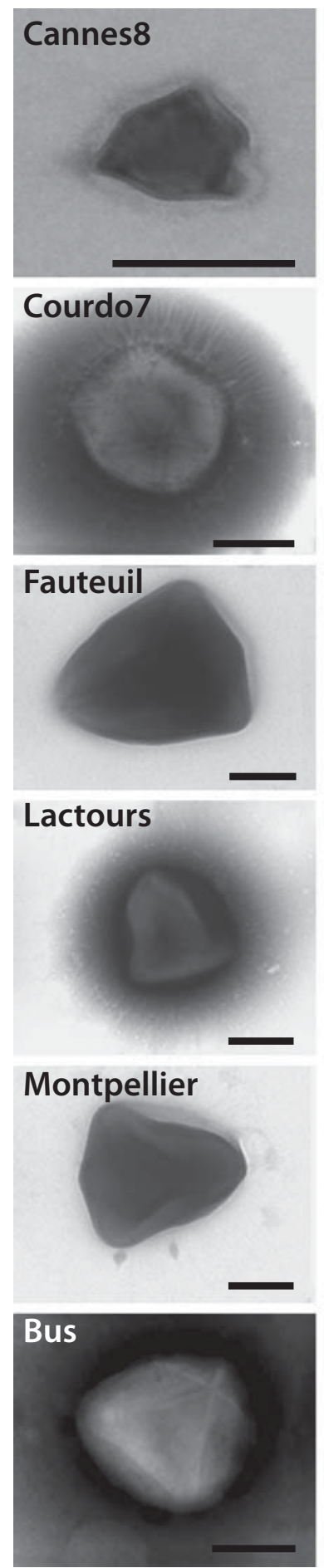
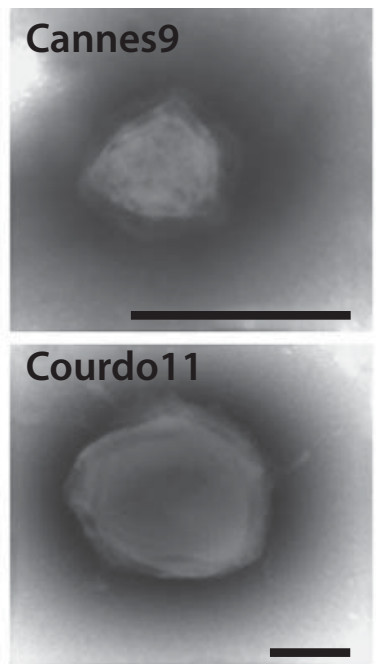

\section{Longchamps}
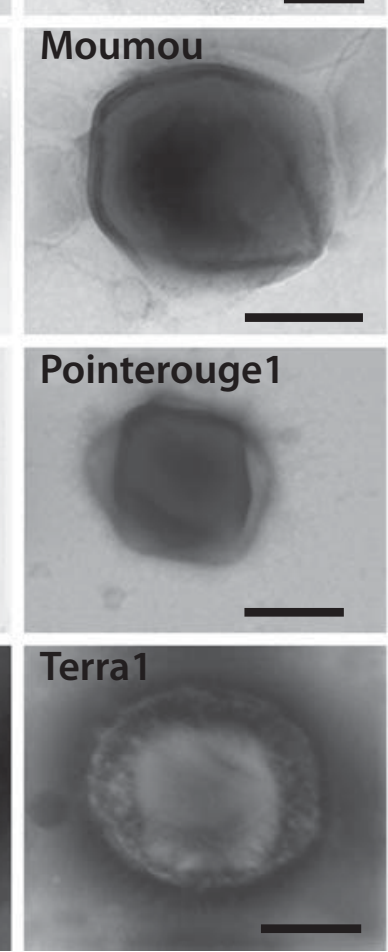
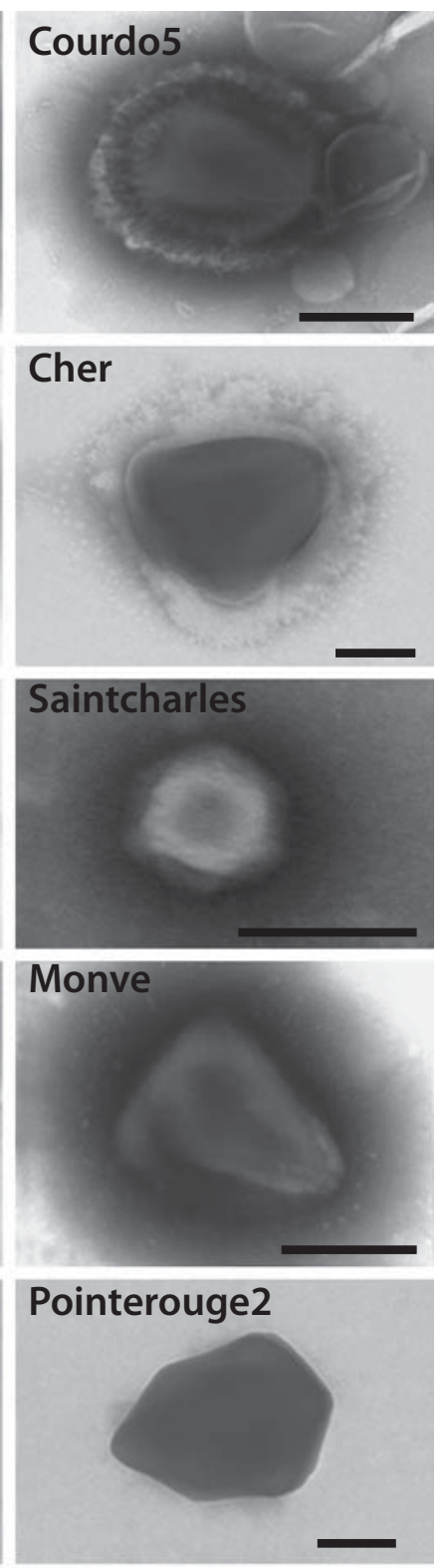

Terra2

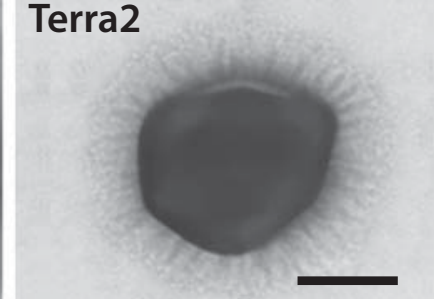

Fig. 2. Negative staining of the new viruses isolated in the present study. $\mathrm{Bar}=200 \mathrm{~nm}$. of the new viruses. However, we observed that all viruses, except Saintcharles, are grouped in a single group. They can then be divided in two clusters: one corresponding to the Mimivirus group with Terra2, Moumou, Monve,
Courdo11 and Terra1, and another cluster with Lentille, Lactours, Pointerouge1, Pointerouge2, Fauteuil, Cher and Longchamps. The virus Saintcharles appears to be a novel virus, but it is impossible to identify its position. Fi- 
Fig. 3. The virus factory of virus Lentille and its virophage. The organization is comparable to that observed with Mamavirus and its virophage, with numerous small viruses of $50 \mathrm{~nm}$ in size disseminated around the virus factory of the giant virus. Bar $=1 \mu \mathrm{m}$.

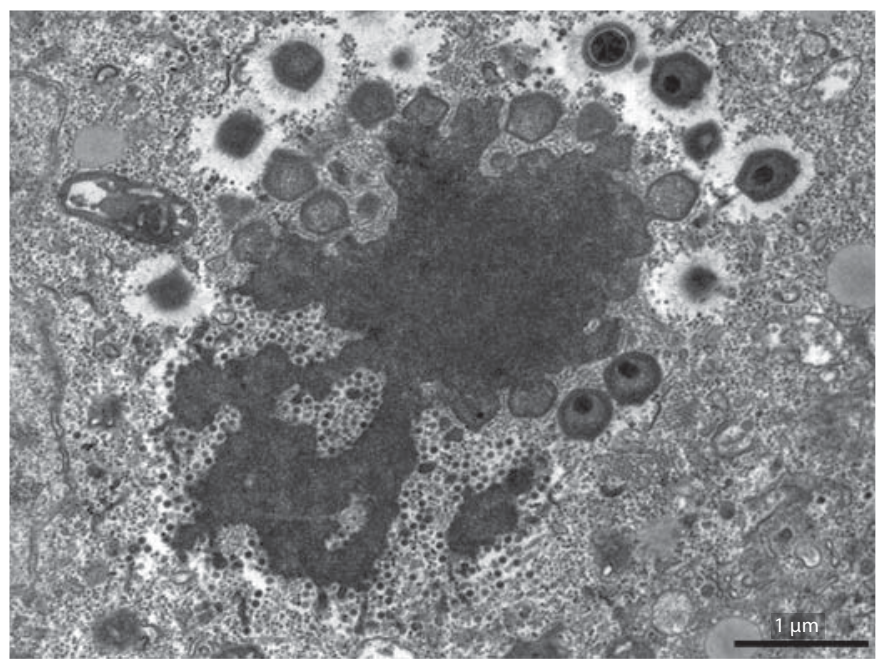

Fig. 4. Phylogenetic tree, built with the PolB sequences of selected NCLDVs, showing clustering of our giant viruses isolated in A. polyphaga.

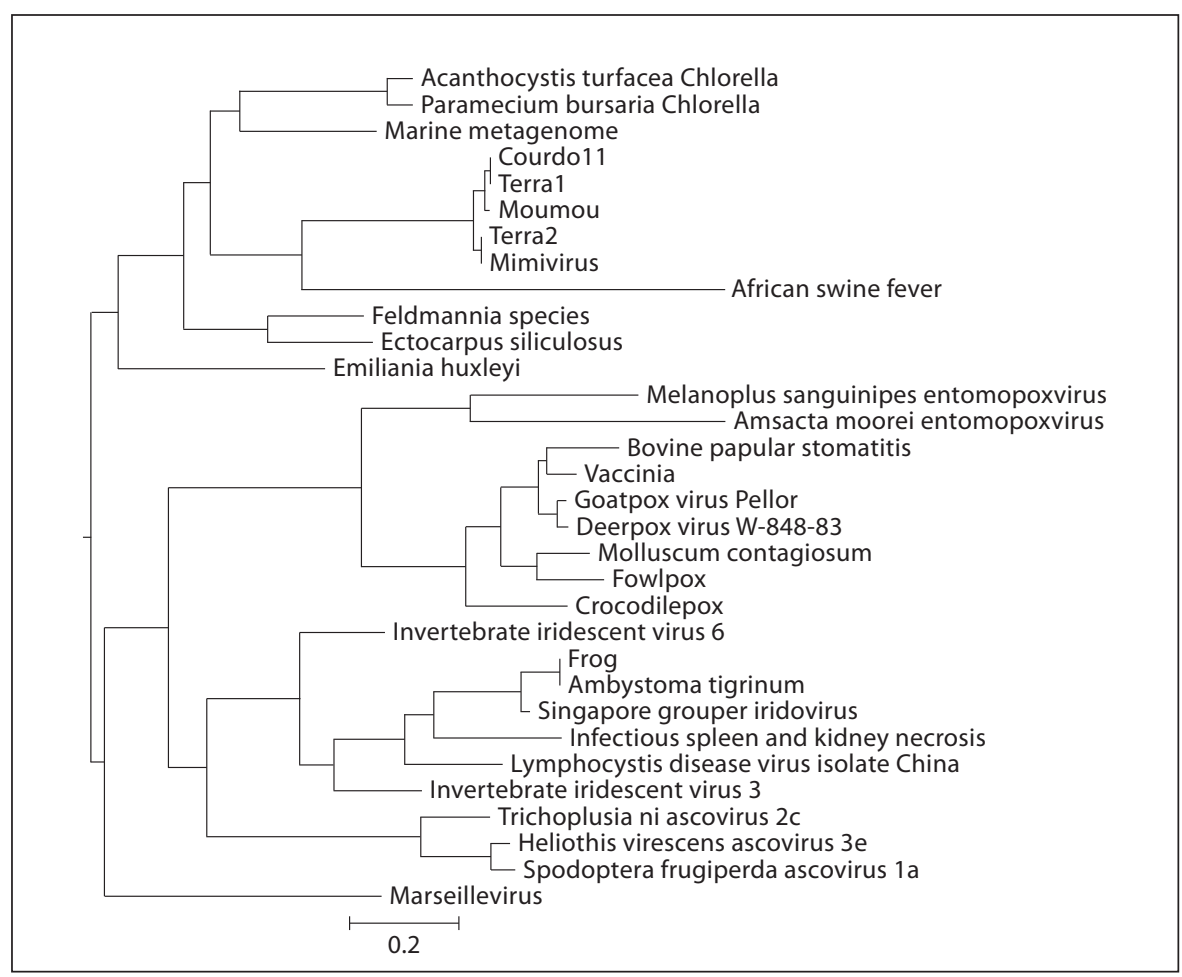

nally, we were not able to obtain a sequence with these PCR primers for the Cannes8 and Cannes9 viruses.

\section{Presumptive Identification Using MALDI-TOF MS}

A MALDI-TOF MS profile was obtained for all of the virus isolates. According to the viruses tested, the number of peaks varied from 13 to 110 (fig. 5). Significant peaks were reproducible and had strong intensities relative to background noise. Mimivirus and Mamavirus were unique in sharing the same spectrum. Much like the PolB sequence analysis, Terra 2 and Mimivirus clustered together (fig. 6). The separation of the Mimivirus cluster (Terra2, Moumou, Monve, Courdo11 and Terra1) resulting from PolB sequencing was also observed. 


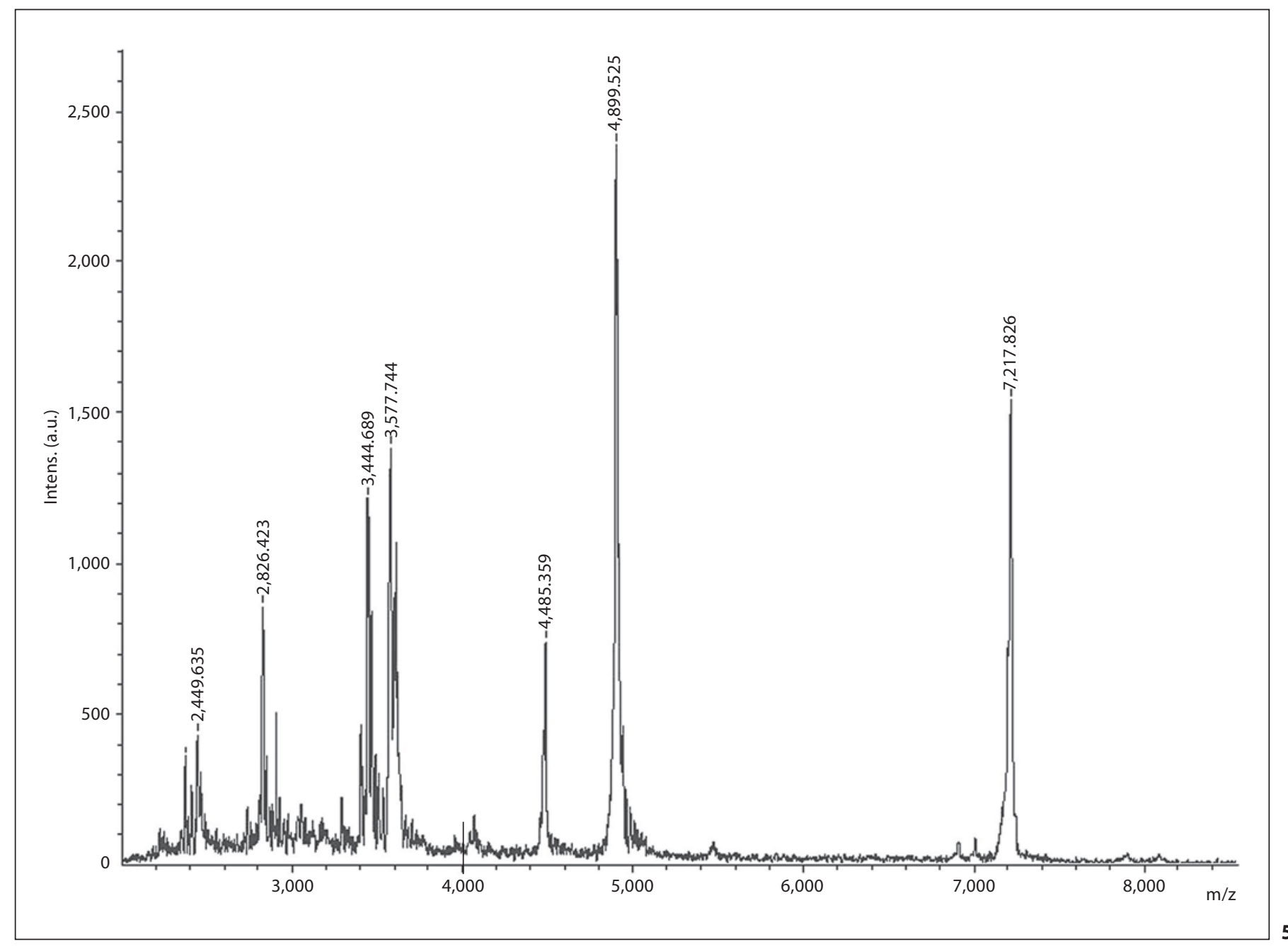

Fig. 5. Example of the spectrum profile of a giant virus (here, Moumou) obtained by using MALDI-TOF MS.

Fig. 6. Dendrogram built by using MALDI-TOF MS data and based on the presence/absence of majors peaks in the profiles of each giant virus spectrum.

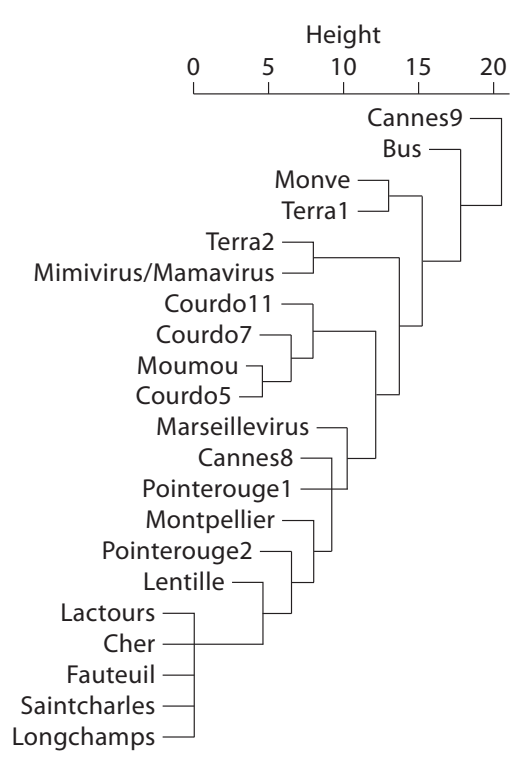




\section{Discussion}

In the present work, we isolated many new giant viruses from diverse environments, a feature that contrasts with our previous studies in which we inoculated hundreds of aquatic and soil samples onto amoebae without isolation of such viruses [15-19]. Curiously, several sequences with high similarity to Mimivirus were detected in two sea metagenomic data sets, and they were suspected to be ubiquitous among theses samples [21, 22]. In a study by Monier et al. examining the relative abundance of PolB fragments for virus groups across GOS sample sites, Mimivirus relatives appeared as the most ubiquitous, after phages, present in $86 \%$ of sample sites tested [22]. By counting overlapping PolB fragments from the same GOS data set onto the Mimivirus group, the authors estimated that at least 85 distinct members of the Mimiviridae group were present. The data presented herein finally confirm the ubiquitous character of Mimivirus relatives, as they were observed in all aquatic environments tested. We show for the first time that Mimivirus relatives are also present in the soil. In fact, this should not be surprising because the unique Mimiviridae hosts known to date are Acanthamoeba, and this group of amoeba is known to be ubiquitous [29].

The isolation of viruses in the present work is related to small modifications in our co-culture protocols. Despite the fact that giant viruses are efficient pathogens that multiply and lead to amoeba lysis more quickly than any other bacterial amoeba pathogens, the presence of bacteria in environmental samples growing in amoebae or in amoeba culture medium masks and/or inhibits the growth of viruses. Thus, by adding selected antibiotics that efficiently kill these bacteria, these viruses could be detected in amoeba co-cultures. This finally confirms that NCLDV are likely highly common in the environment and that other Phycodnaviridae-Mimiviridae viruses are present, as recently suggested by authors who reported the presence of ASFAR-like sequences in sewage in Spain [30].

A unique virophage-like virus was also observed in association with virus Lentille. Its morphology and multiplication mode seems to be comparable to that of the virophage of Mamavirus [20]. The sequencing of its genome is ongoing and should shed light on the evolution of virophages. Additionally, from our data, we hypothesize that virophages of giant viruses are probably also common.

Our tentative approach to identify/classify these viruses based on gene sequence data was not very effec-

Tentative Characterization of New Giant Viruses tive. This is due to the high variability of conserved gene sequences associated with the low $\mathrm{G}+\mathrm{C}$ contents of these genes. We attempted to classify our isolates using PolB gene sequences; the choice of the B-family DNA polymerase was based on a previous study by Iyer et al. that demonstrated that this gene is among the nine genes common to all NCLDV [31,32]. Moreover, it was recently demonstrated to be a gene of choice for phylogenetic characterization of new NCLDVs and research of NCLDV relatives in metagenome data sets [22, 33-35]. This is mostly due to their high sequence conservation level and apparent uncommon lateral gene transfer [3538].

From our data, it was possible to observe that the big viruses (above $350 \mathrm{~nm}$ ) which we isolated belong to a monophyletic cluster among NCLDVs, and that they are part of the Phycodnaviridae. This suggests possible revision in the taxonomy of this group of viruses, as previously suggested in a study based on conserved genes [39, 40] and the whole proteome without alignment, named FFP phylogeny for feature frequency profiles [41]. However, these data need confirmation as it was not possible to obtain complete sequences for this gene. The same problem was previously observed in the Phycodnaviridae, where degenerate PCR primers did not permit amplification from all strains [42]. Among our new isolates, three small viruses (Saintcharles, Cannes 8 and Cannes9) with approximate sizes of $200 \mathrm{~nm}$, much like Marseillevirus, were isolated. For Saintcharles, it was possible to obtain a PolB fragment, and from this sequence it appears that Saintcharles represents a new family of viruses. The genomes of Saintcharles and the other two small viruses will soon be completely sequenced to classify them among the NCLDVs.

As gene sequence-based identification using universal primers was not completely effective, we attempted to use MALDI-TOF MS for the identification of purified viruses. MALDI-TOF MS identification of agar-grown bacteria is currently the most quick and accurate method for their routine identification in the clinical microbiology laboratory [43]. This method has also been used to identify yeasts [44] but not purified viruses. Our results on the perfect identity of Mamavirus and Mimivirus and close relationship between Terra2 and Mimivirus (or between Terral and Courdo11) are in agreement with the PolB sequence data and confirm that it is possible to use MALDITOF MS analysis to avoid complete genome sequencing for preliminary identification of new isolates of giant viruses. The future characterization of the viruses isolated herein will help us to evaluate if phylogeny based on 
MALDI-TOF MS data is congruent with that based on genome sequence data. However, from the current study, MALDI-TOF MS analysis allowed identification of giant viruses of the same species, and thus, should be used as the method of choice for the initial screening of new viruses.

\section{Acknowledgments}

The authors are indebted to Yann Bon Mardion, Philippe Lloret and Mathieu Gravil from Apsytec Equipment (Rousset, France) for providing some of the cooling tower samples.

\section{References}

1 Rodriguez-Zaragoza S: Ecology of free-living amoebae. Crit Rev Microbiol 1994;20: 225-241.

-2 Weekers PH, Bodelier PL, Wijen JP, Vogels GD: Effects of grazing by the free-living soil Amoebae Acanthamoeba castellanii, Acanthamoeba polyphaga, and Hartmannella vermiformis on various bacteria. Appl Environ Microbiol 1993;59:2317-2319.

3 Wang X, Ahearn DG: Effect of bacteria on survival and growth of Acanthamoeba castellanii. Curr Microbiol 1997;34:212-215.

-4 Fritsche TR, Horn M, Wagner M, Herwig RP, Schleifer KH, Gautom RK: Phylogenetic diversity among geographically dispersed Chlamydiales endosymbionts recovered from clinical and environmental isolates of Acanthamoeba spp. Appl Environ Microbiol 2000;66:2613-2619.

5 Hall J, Voelz H: Bacterial endosymbiont of Acanthamoeba sp. J Parasit 1985;71:89-95.

6 Rowbotham TJ: Preliminary report on the pathogenicity of Legionella pneumophila for freshwater and soil amoebae. J Clin Pathol 1980;33:1179-1183.

7 Rowbotham TJ: Current views on the relationships between amoebae, legionellae and man. Isr J Med Sci 1986;22:678-689.

8 Rowbotham TJ: Isolation of Legionella pneumophila from clinical specimens via amoebae, and the interaction of those and other isolates with amoebae. J Clin Pathol 1983;36: 978-986.

-9 Birtles RJ, Rowbotham TJ, Raoult D, Harrison TG: Phylogenetic diversity of intraamoebal legionellae as revealed by $16 \mathrm{~S}$ rRNA gene sequence comparison. Microbiology 1996;142:3525-3530.

$\checkmark 10$ Adeleke AA, Fields BS, Benson RF, Daneshvar MI, Pruckler JM, Ratcliff RM, Harrison TG, Weyant RS, Birtles RJ, Raoult D, Halablab MA: Legionella drozanskii sp. nov., Legionella rowbothamii sp. nov. and Legionella fallonii sp. nov.: three unusual new Legionella species. Int J Syst Evol Mic 2001;51:1151-1160.

- 11 La Scola B, Birtles RJ, Greub G, Harrison TJ Ratcliff RM, Raoult D: Legionella drancourtii sp. nov., a strictly intracellular amoebal pathogen. Int J Syst Evol Microbiol 2004;54: 699-703.

12 Birtles RJ, Rowbotham TJ, Storey C, Marrie TJ, Raoult D: Chlamydia-like obligate parasite of free-living amoebae. Lancet 1997;349: 925-926.
13 Birtles RJ, Rowbotham TJ, Michel R, Pitcher DG, La Scola B, Alexiou-Daniel S, Raoult D: Candidatus Odyssella thessalonicensis gen. nov., sp.nov., an obligate intracellular parasite of Acanthamoeba species. Int J Syst Bacteriol 2000;50:63-71.

14 La Scola B, Audic S, Robert C, Jungang L, de L, X, Drancourt M, Birtles R, Claverie JM, Raoult D: A giant virus in amoebae. Science 2003;299:2033.

15 La Scola B, Barrassi L, Raoult D: Isolation of new fastidious $\alpha$ Proteobacteria and Afipia felis from hospital water supplies by direct plating and amoebal co-culture procedures. FEMS Microbiol Ecol 2000;34:129-137.

16 La Scola B, Mezi L, Auffray JP, Berland Y, Raoult D: Patients in the intensive care unit are exposed to amoeba-associated pathogens. Infect Control Hosp Epidemiol 2002; 23:462-465.

17 La Scola B, Boyadjiev I, Greub G, Khamis A, Martin C, Raoult D: Amoeba-resisting bacteria and ventilator-associated pneumonia. Emerg Infect Dis 2003;9:815-821.

18 Pagnier I, Raoult D, La Scola B: Isolation and identification of amoeba-resisting bacteria from water in human environment by using an Acanthamoeba polyphaga co-culture procedure. Environ Microbiol 2008;10:11351144.

19 Evstigneeva A, Raoult D, Karpachevskiy L, La Scola B: Amoeba co-culture of soil specimens recovered 33 different bacteria, including four new species and Streptococcus pneumoniae. Microbiology 2009;155:657-664.

20 La Scola B, Desnues C, Pagnier I, Robert C, Barrassi L, Fournous G, Merchat M, SuzanMonti M, Forterre P, Koonin E, Raoult D: The virophage as a unique parasite of the giant Mimivirus. Nature 2008;455:100-104.

21 Ghedin E, Claverie JM: Mimivirus relatives in the Sargasso sea. Virol J 2005;2:62.

22 Monier A, Claverie JM, Ogata H: Taxonomic distribution of large DNA viruses in the sea. Genome Biol 2008;9:R106.

23 La Scola B, Mezi L, Weiller PJ, Raoult D: Isolation of Legionella anisa using an amoebal coculture procedure. J Clin Microbiol 2001; 39:365-366.

24 Gimenez DF: Staining Rickettsiae in yolksac cultures. Stain Technol 1964;39:135-140.
25 Suzan-Monti M, La Scola B, Barrassi L, Espinosa L, Raoult D: Ultrastructural characterization of the giant volcano-like virus factory of Acanthamoeba polyphaga Mimivirus. PloS One 2007;2:e328.

-26 Drancourt M, Bollet C, Carlioz A, Martelin R, Gayral JP, Raoult D: 16S ribosomal DNA sequence analysis of a large collection of environmental and clinical unidentifiable bacterial isolates. J Clin Microbiol 2000;38: 3623-3630.

27 Raoult D, Audic S, Robert C, Abergel C, Renesto P, Ogata H, La Scola B, Suzan M, Claverie JM: The 1.2-megabase genome sequence of Mimivirus. Science 2004;306: 1344-1350.

28 Margulies M, Egholm M, Altman WE, Attiya S, Bader JS, Bemben LA, Berka J, Braverman MS, Chen YJ, Chen Z, Dewell SB, Du L, Fierro JM, Gomes XV, Godwin BC, He W, Helgesen S, Ho CH, Irzyk GP, Jando SC, Alenquer ML, Jarvie TP, Jirage KB, Kim JB, Knight JR, Lanza JR, Leamon JH, Lefkowitz SM, Lei M, Li J, Lohman KL, Lu H, Makhijani VB, McDade KE, McKenna MP, Myers EW, Nickerson E, Nobile JR, Plant R, Puc BP, Ronan MT, Roth GT, Sarkis GJ, Simons JF, Simpson JW, Srinivasan M, Tartaro KR, Tomasz A, Vogt KA, Volkmer GA, Wang $\mathrm{SH}$, Wang Y, Weiner MP, Yu P, Begley RF, Rothberg JM: Genome sequencing in microfabricated high-density picolitre reactors. Nature 2005;437:376-380.

29 Khan NA: Acanthamoeba. Norwich, Caister Academic Press, 2009.

30 Loh J, Zhao G, Presti RM, Holtz LR, Finkbeiner SR, Droit L, Villasana Z, Todd C, Pipas JM, Calgua B, Girones R, Wang D, Virgin HW: Detection of novel sequences related to African swine fever virus in human serum and sewage. J Virol 2009;83:13019-13025.

-31 Iyer LM, Aravind L, Koonin EV: Common origin of four diverse families of large eukaryotic DNA viruses. J Virol 2001;75: $11720-11734$.

-32 Iyer LM, Balaji S, Koonin EV, Aravind L: Evolutionary genomics of nucleo-cytoplasmic large DNA viruses. Virus Res 2006;117: 156-184.

33 Short SM, Suttle CA: Sequence analysis of marine virus communities reveals that groups of related algal viruses are widely distributed in nature. Appl Environ Microbiol 2002;68:1290-1296.
La Scola/Campocasso/N’Dong/ Fournous/Barrassi/Flaudrops/Raoult 
34 Braithwaite DK, Ito J: Compilation, alignment, and phylogenetic relationships of DNA polymerases. Nucleic Acids Res 1993; 21:787-802.

-35 Filee J, Forterre P, Sen-Lin T, Laurent J: Evolution of DNA polymerase families: evidences for multiple gene exchange between cellular and viral proteins. J Mol Evol 2002;54: 763-773.

36 Chen F, Suttle CA: Evolutionary relationships among large double-stranded DNA viruses that infect microalgae and other organisms as inferred from DNA polymerases genes. Virology 1996;219:170-178.

>37 Allen MJ, Martinez-Martinez J, Schroeder DC, Somerfield PJ, Wilson WH: Use of microarrays to assess viral diversity: from genotype to phenotype. Environ Microbiol 2007;9:971-982.
38 Villarreal LP, DeFilippis VR: A hypothesis for DNA viruses as the origin of eukaryotic replication proteins. J Virol 2000;74:70797084.

39 Monier A, Larsen JB, Sandaa RA, Bratbak G, Claverie JM, Ogata H: Marine Mimivirus relatives are probably large algal viruses. Virol J 2008;5:12.

40 Larsen JB, Larsen A, Bratbak G, Sandaa RA: Phylogenetic analysis of members of the Phycodnaviridae virus family, using amplified fragments of the major capsid protein gene. Appl Environ Microbiol 2008;74:3048-3057.

41 Wu GA, Jun SR, Sims GE, Kim SH: Wholeproteome phylogeny of large dsDNA virus families by an alignment-free method. Proc Natl Acad Sci USA 2009;106:12826-12831.
42 Sandaa RA, Heldal M, Castberg T, Thyrhaug $\mathrm{R}$, Bratbak $\mathrm{G}$ : Isolation and characterization of two viruses with large genome size infecting Chrysochromulina ericina (Prymnesiophyceae) and Pyramimonas orientalis (Prasinophyceae). Virology 2001;290:272-280.

43 Seng P, Drancourt M, Gouriet F, La SB, Fournier PE, Rolain JM, Raoult D: Ongoing revolution in bacteriology: routine identification of bacteria by matrix-assisted laser desorption ionization time-of-flight mass spectrometry. Clin Infect Dis 2009;49:543551.

44 Qian J, Cutler JE, Cole RB, Cai Y: MALDITOF mass signatures for differentiation of yeast species, strain grouping and monitoring of morphogenesis markers. Anal Bioanal Chem 2008;392:439-449. 